\title{
The Summer Air-Spora of Two Contrasting Adjacent Rural Sites
}

\author{
By MAUREEN E. LACEY* \\ Rothamsted Experimental Station, Harpenden, Hertfordshire
}

(Received 22 January 1962)

\begin{abstract}
SUMMARY
The air in a valley near a stream and in an exposed site on a small hill at Silwood Park, near Ascot, Berkshire, was sampled from 14 May to 25 September 1958 at half a metre above the ground by a Hirst automatic volumetric spore trap. Seasonal periodicities of 26 categories of fungus spores and 7 categories of pollen grains are given as 6 -day running means of the daily average number of spores per cubic metre of air. Estimated hourly concentrations of spores for 6 consecutive days are given for three fungus spore types and two pollens. The diurnal periodicity is given for these groups. There were $\mathbf{2 \cdot 6}$ times more spores at site $S$ near the stream than at the exposed site M. There were 4.9 times more spores of ascomycetes at $\mathrm{S}$ than at $\mathbf{M}, 3$ times as many spores of basidiomycetes but only $\mathbf{1} \cdot \mathbf{4}$ times as many from fungi imperfecti. The proportion of the different types of spores at the two sites varied; $14 \%$ of spores at $\mathrm{S}$ were from ascomycetes, $7 \%$ at $M ; 17.5 \%$ of those at $S$ were from fungi imperfecti and $32 \%$ of those at $\mathbf{M}$. Tree pollen grains were equal in number at both sites but there was $2 \cdot 8$ times more grass pollen and 6.5 times more weed pollen at $\mathbf{S}$ than at $\mathbf{M}$. Urtica pollen was 8.1 times as common at $S$ and made up $55 \%$ of the total pollen in that area, but only $24 \%$ of the total at $\mathrm{M}$, mainly because of the local abundance of nettle plants. The results suggest that the ecology of an area has a major influence on its air-spora through local flora and microclimate.
\end{abstract}

\section{INTRODUCTION}

The Hirst automatic volumetric spore trap (Hirst, 1952) has been used to study the seasonal and diurnal periodicities of components of the air-spora in several localities. Hirst (1952) and Gregory \& Hirst (1957) studied the summer air-spora at 2 and $24 \mathrm{~m}$. above ground at Rothamsted Experimental Station in an area typical of mixed farming in the south of England. The air-spora at Rothamsted was also studied by Sreeramulu (1959) who discussed the seasonal and diurnal periodicity of spores of some plant pathogens, and by Hamilton (1959) who compared it with the air-spora of an urban area in London. A contrasting estuarine area was studied by Gregory \& Sreeramulu (1958). These workers all concluded that the air-spora of any locality may come from local sources, but two sites of differing ecological type situated near together have never been compared. In connexion with studies on how environment affects asthma and hay fever (Maunsell, 1958), Dr K. Maunsell suggested that two traps should be run simultaneously, one near a stream and one in an exposed area. The Imperial College Field Station, Silwood Park, Sunninghill,

\section{* Née Maureen E. Bunce.}


near Ascot, Berkshire, provided suitable sites to see whether the air near a stream or river contained spores or pollen differing from that in the drier areas studied hitherto.

\section{METHODS}

Two Hirst spore traps were operated continuously at Silwood Park from 14 May to 25 September 1958. One trap ( $\mathrm{S}$ in Fig. 1 ) was about $4 \mathrm{ft}$. from a small stream and $10 \mathrm{ft}$. from a garden wall running parallel with the stream. The area was in a valley sheltered by the $10 \mathrm{ft}$. wall to the east and trees and shrubs including elder and

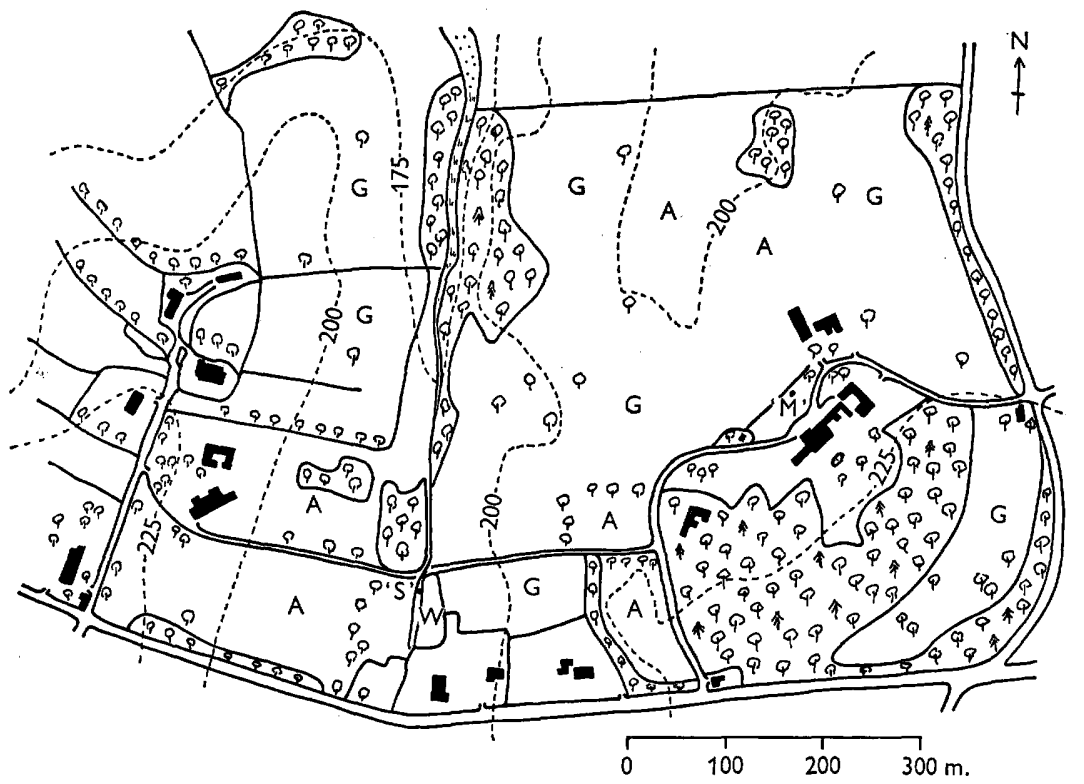

Fig. 1. Map showing position of traps $M$ and $S$ in 1958 at Imperial College Field Station, Silwood Park, Sunninghill, near Ascot, Berkshire. $S=$ trap at stream; $M=$ trap in meteorological enclosure; $\mathbf{W}=$ walled garden; $\mathbf{A}=$ arable; $\mathbf{G}=$ grass. Based on the Ordnance Survey Map with the sanction of the controller of H.M. Stationery Office.

willow on the other three sides; in the nearby wooded area elm and oak predominated; the ground vegetation consisted mainly of grasses, nettles and other weeds. The second trap, M, was in the meteorological enclosure on a closely cut lawn $450 \mathrm{~m}$. E.N.E. of site $\mathrm{S}$, and $12 \mathrm{~m}$. higher on a flat area on a small hill. This site was relatively open and well exposed to winds from the west and north-west; with buildings and ornamental trees on the other sides, the valley to the north-west was grass and arable.

The orifice of each trap was $0.5 \mathrm{~m}$. above ground level. The slides were changed daily at approximately $09.00 \mathrm{hr}$. G.M.T.; trap M was always changed first. Air was sampled at the rate of $10 \mathrm{l} . / \mathrm{min}$. The slides were coated with petroleum jelly with $12.5 \%$ paraffin wax as described by Hirst (1953). After exposure they were at once mounted in glycerol jelly under a coverglass, and stored until they were scanned two years later.

Daily mean concentrations of spores and pollen grains $/ \mathrm{m}^{3}$ were estimated from counts made on 'long traverses' (Hirst, 1953, p. 378) under a $3.75 \mathrm{~mm}$. oil-immersion 
objective and are given uncorrected for variations in trapping efficiency depending on wind speed or particle size. Traverses were $30 \mu$ wide for most kinds of fungus spores but $60 \mu$ wide for large spores, algal clumps, fern spores and pollen grains. Hourly concentrations were estimated from 'short traverses' on selected days only (see pp. 493 and 496) to study diurnal periodicity and correlation with weather. Many kinds of spores counted in this series are illustrated in Gregory (1961) and of pollen in Hyde \& Adams (1958).

Weather. Meteorological records were taken in the enclosure containing trap $\mathbf{M}$. The average daily relative humidity was judged by eye from $24 \mathrm{hr}$. charts. The summer of 1958 was cool and damp, with July the warmest, sunniest and driest month. June had most rain but the relative humidity remained low at an average of $80 \%$. August and September were wet with average humidity above $85 \%$, as shown in Fig. 2. Separate meteorological data were not obtained from site S, but humidities must have usually been higher.

\section{RESULTS}

\section{Fungus spores}

Fungus spores were counted in the thirty-two categories listed in Table 1. A few spores were identified as far as species (e.g. Polythrincium trifolii) but others were only classified into large, more or less arbitrary, groups. Fig. 2 shows the components of the air-spora as estimated number of spores $/ \mathrm{m} .^{3}$ of air, and the seasonal trends of weather calculated as 6-day running means but plotted only at 3-day intervals. There were usually many more spores at site $S$ than at $M$, particularly those that are dispersed in rain or dew, or from species that grow in damp localities, but a few of the dry-spored Fungi Imperfecti and the larger Basidiomycetes were more plentiful in the drier area near trap $M$.

\section{Seasonal variations in the spore content of the air}

With growing knowledge of the air-spora, more spores can be identified than previously. Even though the group described is arbitrary, an attempt is made below to describe those spores included in it. Any spores not classifiable into these categories were included at the end of Table 1 under the heading 'other spores'.

Phycomycetes. Among recognizable Phycomycetes only spores of the Peronospora type were plentiful enough to present separately, although in July there were many of a spore type provisionally attributed to the Entomophthoraceae.

Ascomycetes. The group referred to provisionally as ' 3 -bar ascospores' are very distinctive; they are hyaline and crescent-shaped, with a very thin outer wall contrasting with the three, thick, highly refractile septa (Gregory, 1961, pl. 5, fig. 10). They were 10.5 times more numerous at site $S$ than at $M$. Nothing is known of their origin, but the fungus is possibly a discomycete most prevalent in damp areas. A large proportion of the ascospores found in the air near a stream in the New Forest (Gregory, 1954; and verbal communication) were spores of this type.

The group termed 'fusiform ascospores' are yellow to brown, septate ascospores mainly belonging to the genus Leptosphaeria. Hyaline fusiform spores lacking pedicels or facets of attachment were counted with 'other ascospores', as were spores of Venturia and Chaetomium. The 'Sordaria-type' includes brown unicellular spores such as Xylaria. 'Filiform ascospores' are the long, narrow, generally 


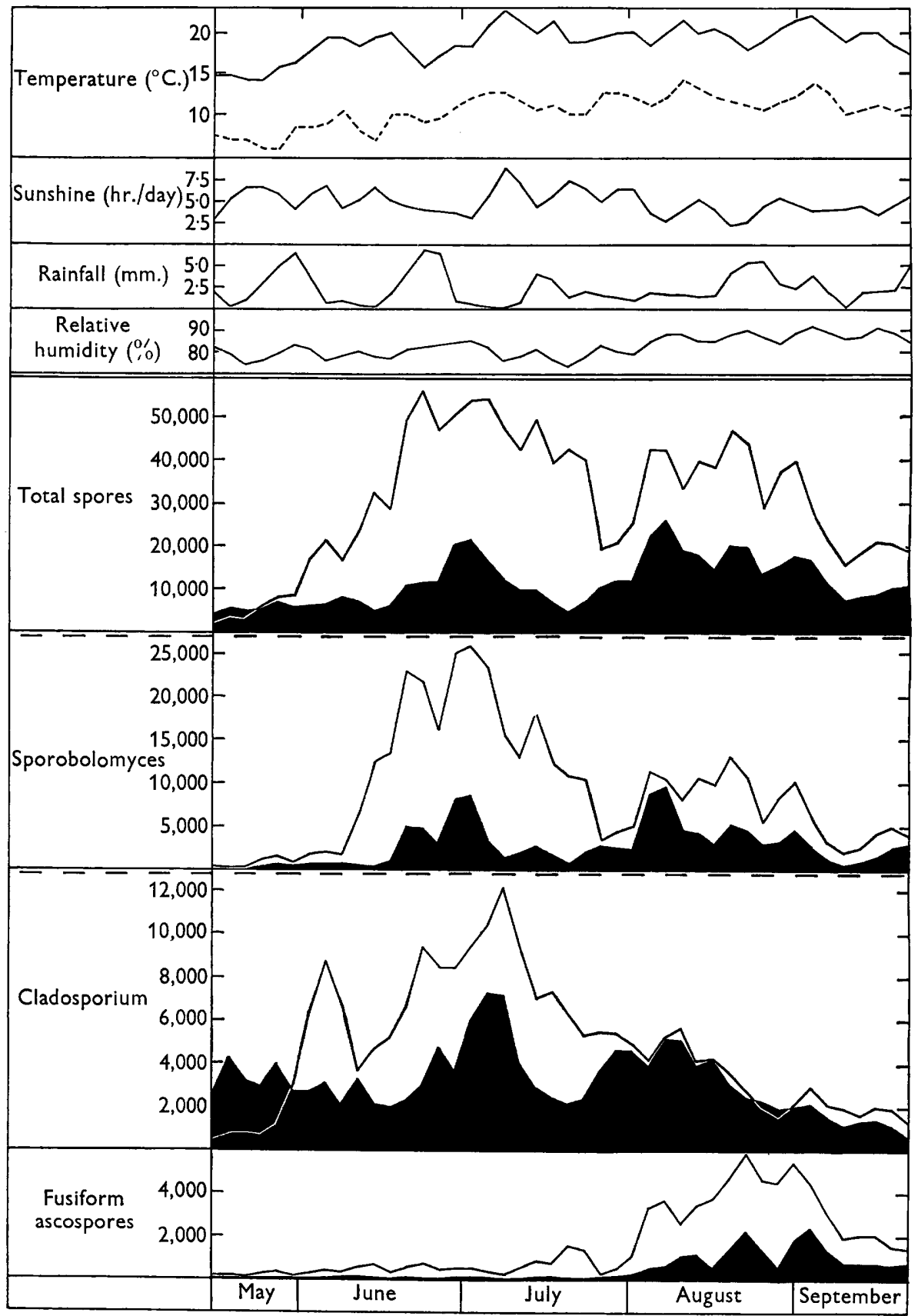

Fig. 2a. Weather and seasonal periodicity of fungus spore and pollen grain concentration $/ \mathrm{m}^{3}$ air at $0.5 \mathrm{~m}$. above ground level, 14 May to 25 September 1958. Curves are 6-day running means plotted at 3-day intervals. 'Temperature: solid line-maximum temperature; broken line-minimum temperature. Line--trap S; shaded area-trap $M$. 
septate, hyaline to pale brown spores which are usually released in rain. Ascomycetes as a group grow and release their spores in damp conditions, and it is not surprising that there were $\mathbf{4 . 9}$ times more ascospores in the air at site $S$ than at site $\mathrm{M}: 14 \%$ of the spores at site $\mathrm{S}$ were classified as ascospores but only $7 \%$ at site M.

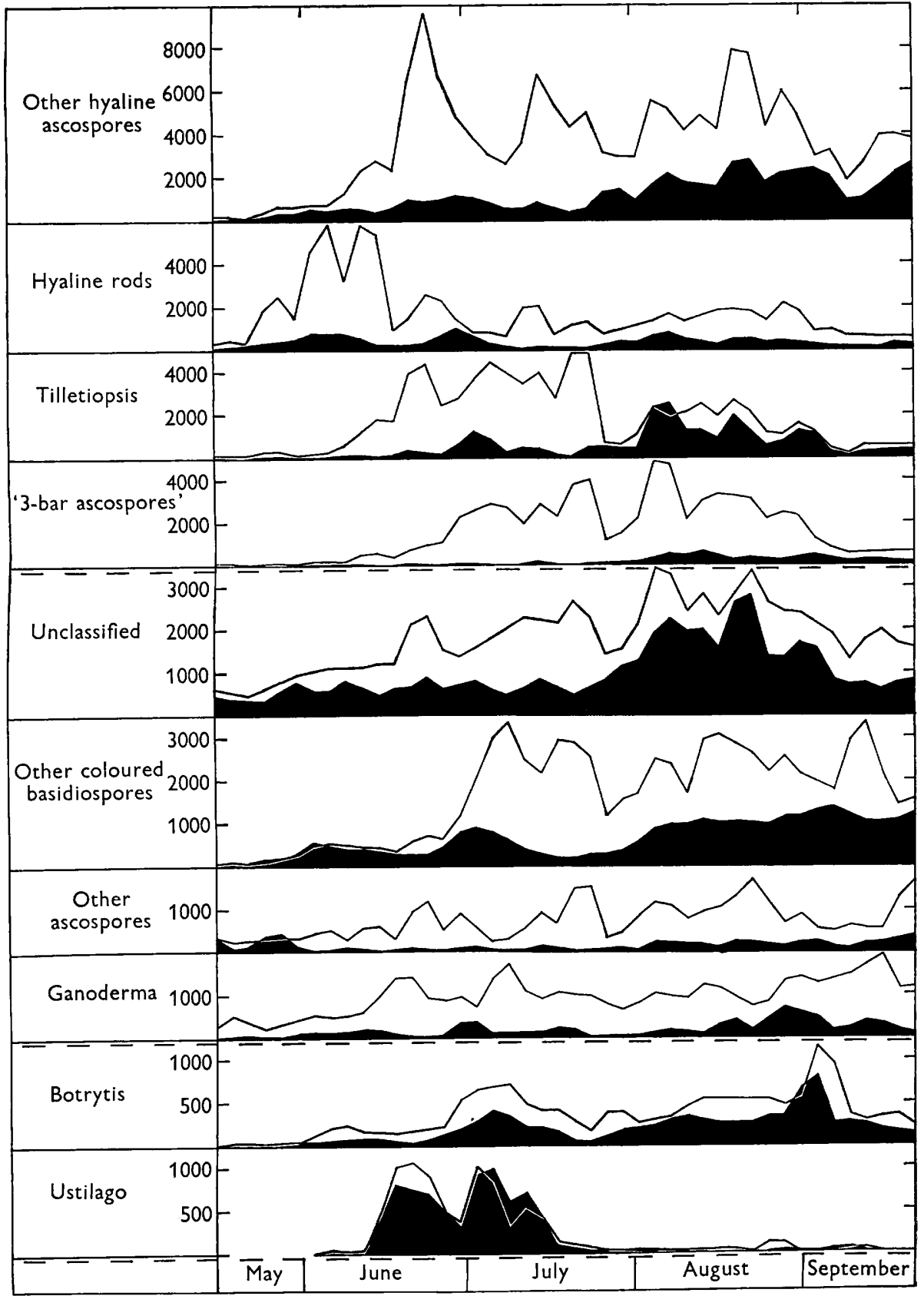

Fig. $2 b$. For legend see page 488 . 
Basidiomycetes. At site S $57 \%$ of the spores, and at site $\mathrm{M} 49 \%$, were recognizable as spores of basidiomycetes (ballistospores, uredospores or smut spores). Altogether there were 3 times more basidiospores at $\mathbf{S}$ than at $\mathbf{M}$, but more spores of some of the cap fungi occurred at M, e.g. Boletus and Nolanea staurospora types. The numbers of smut spores of the Ustilago avenae (perennans) type were very

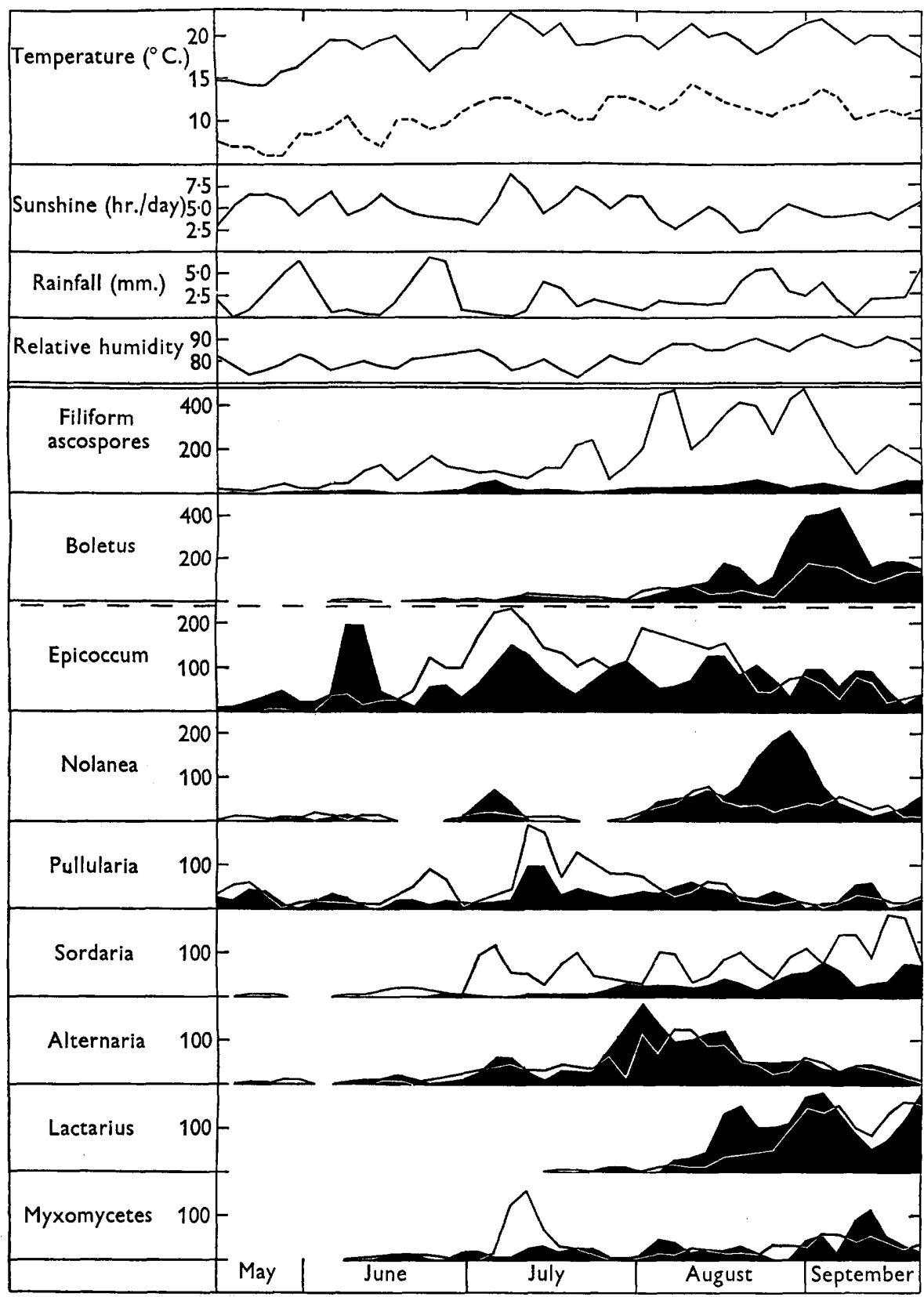

Fig. 2c. For legend see page 488 . 
similar at both sites during the short season when they occurred; a decrease in numbers in late June coincided with a spell of cool rainy weather. The shadow yeasts, Sporobolomyces and Tilletiopsis, were three times as common at $\mathbf{S}$ as at $\mathbf{M}$. The group referred to as 'other hyaline basidiospores' included all the larger hyaline

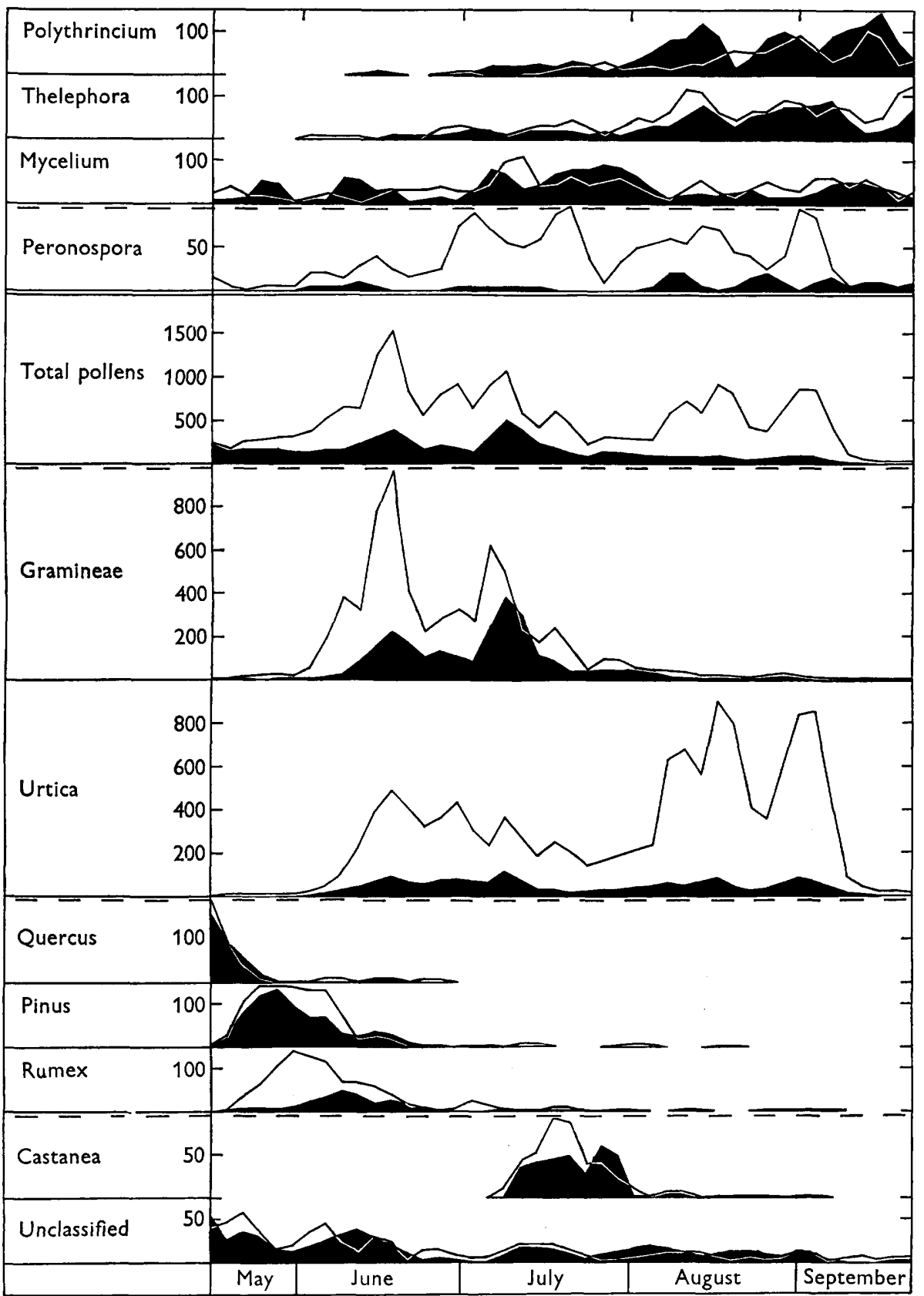

Fig. $2 d$. For legend see page 488 . 
spores with a typical ballistospore hilum but which lacked the surface markings characteristic of the Lactarius and Russula group. The abundance of Ganoderma at site $\mathrm{S}$ was associated with the presence of some large fruit-bodies of G. applanatum at about $65 \mathrm{~m}$. west of the trap. The coloured basidiospores counted separately (Psilocybe, Thelephora) are distinctive types. The groups referred to as 'other coloured basidiospores' include a few Coniophora; with more study many further

Table 1. Contributions of different categories of fungus spores to the air-spora

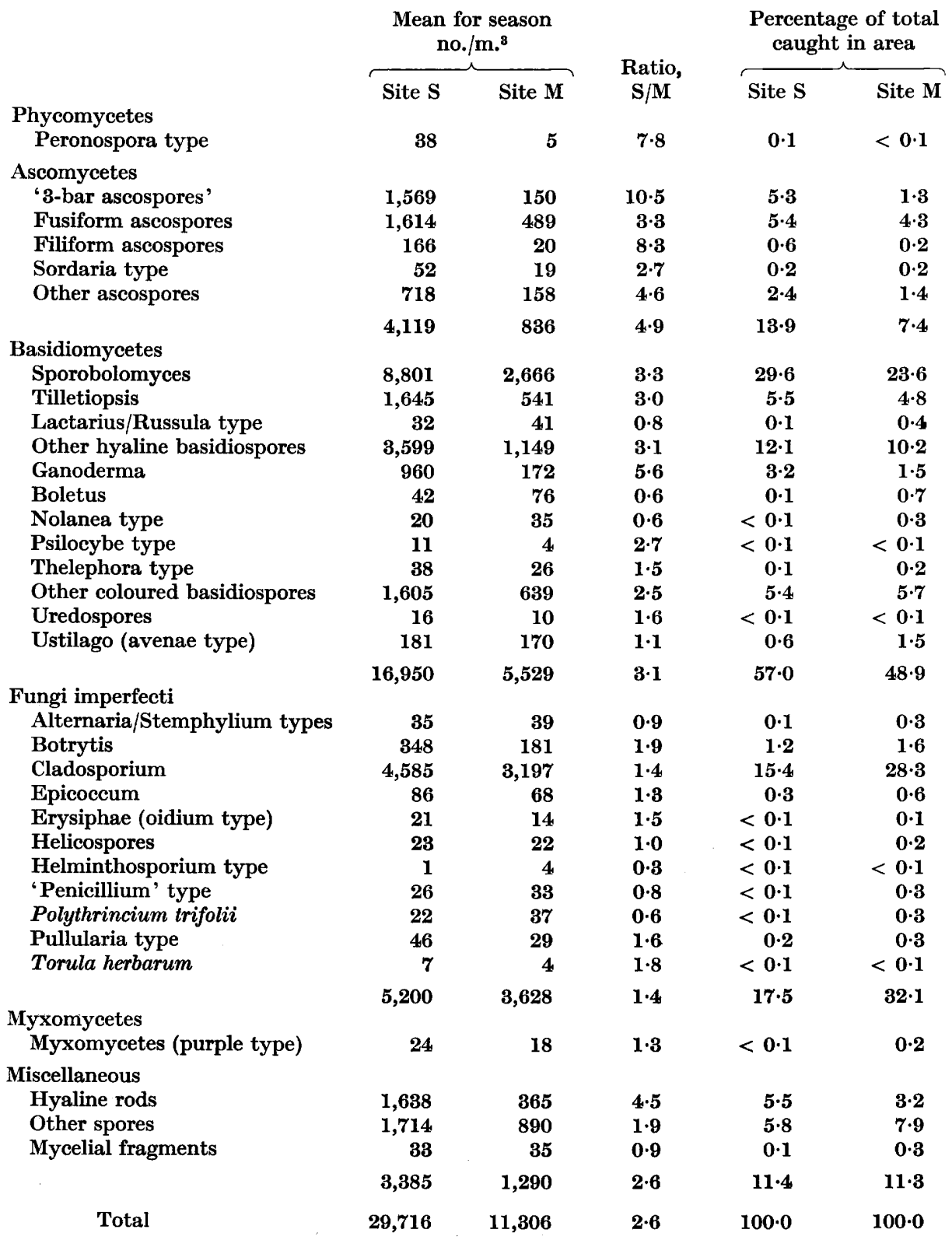


basidiospore types could have been distinguished. Uredospores were not abundant and many of those caught resembled Melampsoridium.

Fungi imperfecti. At both sites $88 \%$ of the spores of Fungi imperfecti were Cladosporium, a common air-borne allergen. Unlike most spore types Cladosporium was more numerous at site $\mathbf{M}$ at the beginning of the season, but in June and July there were more at site $S$; at the end of the season numbers were similar at both sites.

Helminthosporium, 'Penicillium type' and Polythrincium trifolii (all 'dry spores') were all more abundant at site $\mathbf{M}$. The 'Penicillium type' includes single, chains or groups of small round spores about $4 \mu$ in diameter.

Pithomyces chartarum (syn. Sporidesmium bakeri). The occurrence of this fungus in Europe was first indicated by the presence of a few spores on this series of slides (Lacey \& Gregory, 1962): at site S 3 spores on 7 July at 17.00-21.00 hr.; at site M 1 spore each on 7 July at about $17.00 \mathrm{hr}$. and on 21 July at about noon.

Myxomycetes. Those spores of myxomycetes which could be distinguished for purposes of the count were recognized by their subspherical shape, their irregular surface markings and their mauvish-brown colour: they differ from spores of Tilletia which are spherical, and yellowish with distinct honeycomb markings.

Miscellaneous. At both sites $11 \%$ of the spores trapped are placed in this category, which includes among others several distinct spores whose origin and affinity are obscure. 'Hyaline rods' is a term given to small, rod-shaped hyaline spores (Gregory \& Hirst, 1957), which are possibly ascospores of the Discomycete genus Orbilia. 'Mycelial fragments' usually consist of broken pieces of conidiophore of Cladosporium.

\section{Hourly variations in spore content of the air}

In an attempt to correlate weather with the number of spores in the air, three types of spores were counted at hourly intervals for the period 19-24 July (Fig. 3). This period was chosen because it included wet and dry days, and the numbers of spores varied greatly from day to day. The same counts were also used to detect any pronounced diurnal periodicity in spore concentration (Fig. 4), by summing the numbers of spores at each hour of the day separately, expressing the highest total as $100 \%$ and the totals at other hours as a percentage of this. The spore types were selected for diversity and distinctiveness. The ' 3 -bar ascospore' type is easily recognized and known to be a component of the damp air-spora. Ganoderma is an easily recognizable basidiospore type. Botrytis was chosen as a hyphomycete known to release more spores by day.

'3-bar ascospores' were previously thought to be liberated when wetted by rain but, as Fig. 3 shows, very few occurred in the air by day even after rain, but numbers increased consistently at night. This is particularly evident on the diurnal periodicity graph for site S (Fig. 4). Possibly this species can liberate its spores when wetted with rain or even with dew only, but is inhibited by light.

Ganoderma. The diurnal periodicity shown in Figs. 3 and 4 confirms previous reports that spore concentrations are higher at night, but it is not clear from the meteorological records why there were many more spores on some nights than others. Possibly with a point source so near to trap $S$ any differences in wind direction would have a large effect on the concentration reaching the orifice. 


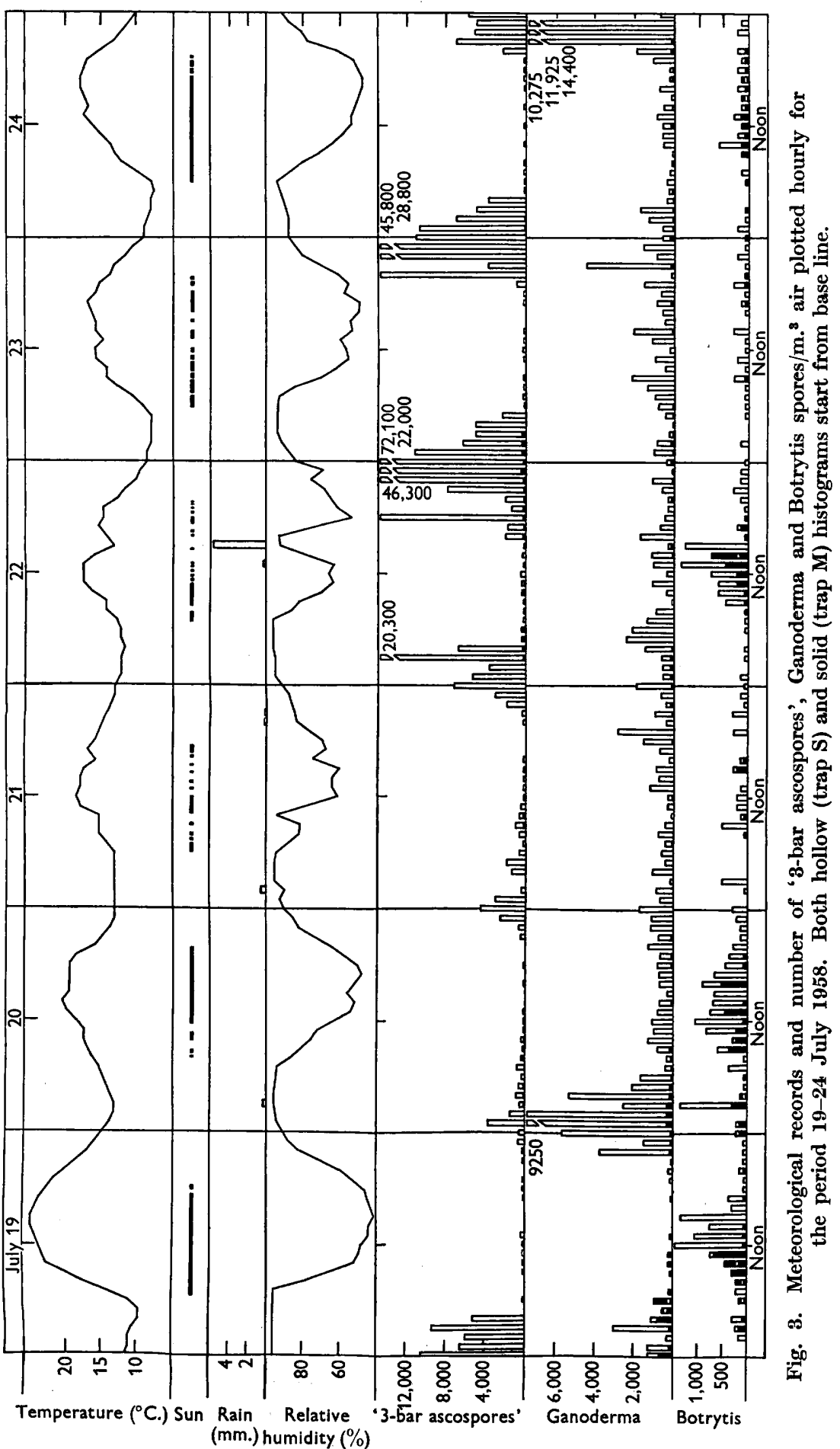


Botrytis was again in the air more by day than by night (Fig. 4) at both sites, but it is difficult to correlate the numbers of spores with variations in weather (Fig. 3).
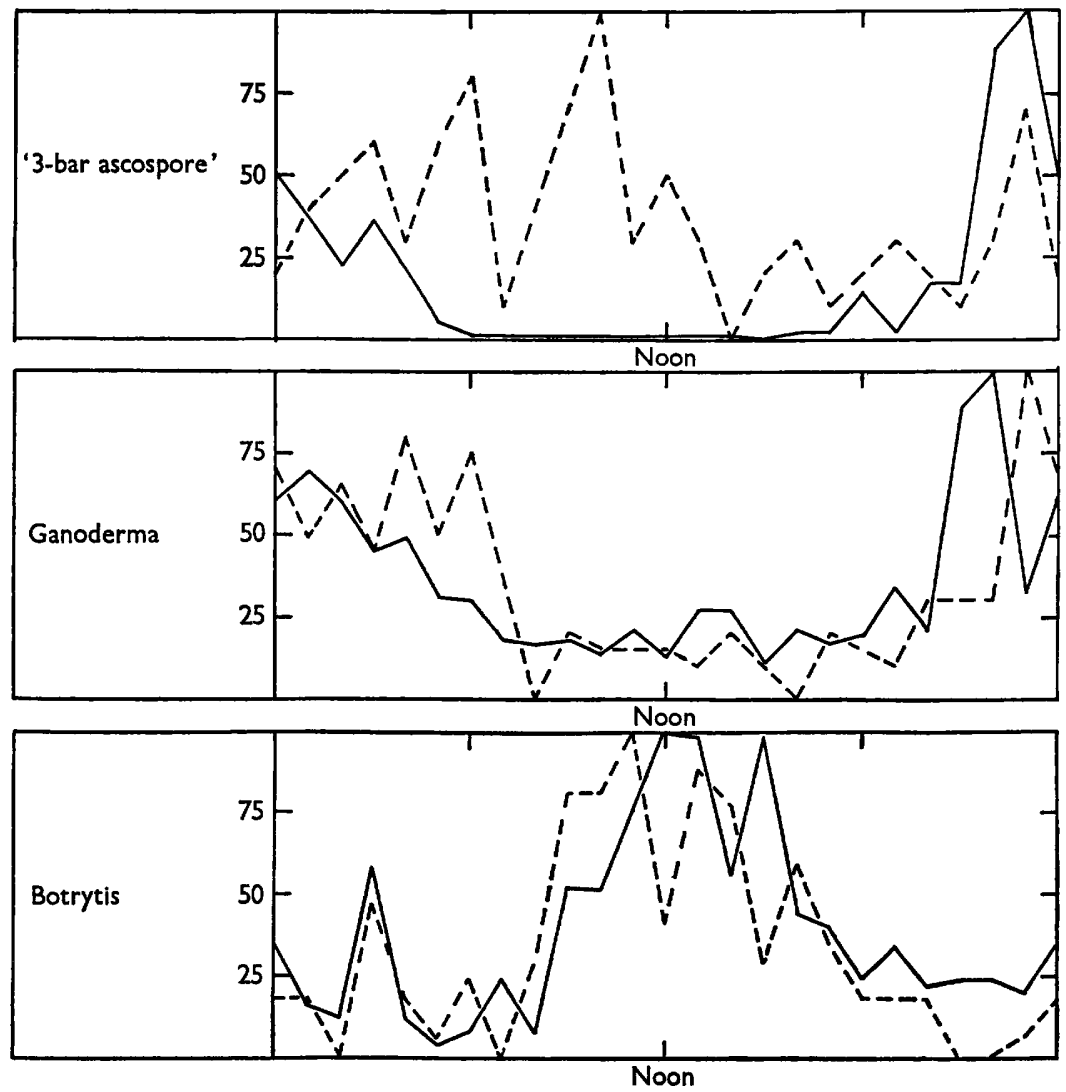

Fig. 4. Diurnal periodicity of '3-bar ascospores', Ganoderma and Botrytis. (Arithmetic mean of data from 19 to 24 July 1958.) - trap S; - - -trap M.

\section{Pollen grains}

Pollen grains are relatively easy to identify because of their size. Table 2 gives the peak concentrations and seasonal totals of the most abundant types. Fig. $2 d$ gives the seasonal variation plotted as 6-day running means. Tree pollen grains were equally numerous at the two sites, but the two most abundant types, grass (Gramineae) and nettle (Urtica), were three and eight times more numerous near the stream than at the hill site.

\section{Seasonal variations in pollen content of the air}

Tree pollens. The numbers of tree pollen grains were similar at both sites, presumably because pollen from a tall tree is easily carried to some distance, so the presence of a local source is less important for traps near ground level than with a groundlevel source. Trapping was started at the end of the Quercus season. Pine pollen was most abundant in late May and June, and Castanea in July. 'Other' tree 
pollens recorded include Acer, Aesculus, Betula, Fagus, Sambucus, Taxus and Tilia, all of which occurred at times similar to those reported by Hyde (1956).

Grass pollen. The main season for grass pollen is June and the first half of July. The fall in number at both sites in late June was associated with a period of relatively cool, rainy weather.

Weed pollen. Most weed pollens during the season were from Urtica which average 35 grains $/ \mathrm{m}^{3}$ at site $\mathrm{M}$ and 283 at site $\mathrm{S}$. This type was also remarkable for the long duration of its season, which persisted from mid-June to early September (see Hyde, 1959). Rumex was the only other plentiful weed pollen and occurred mostly in May and June. Other weed pollens included Artemisia and other Compositae, Chenopodium, Plantago, Ranunculaceae and Umbelliferae.

Table 2. Contributions of different categories of pollens to the air-spora

\begin{tabular}{|c|c|c|c|c|c|}
\hline \multirow[b]{2}{*}{ Tree pollen } & \multicolumn{2}{|c|}{$\begin{array}{c}\text { Seasonal totals } \\
\text { no. } / \mathrm{m} .^{3}\end{array}$} & \multirow{2}{*}{$\begin{array}{l}\text { Ratio } \\
\mathbf{S} / \mathbf{M}\end{array}$} & \multicolumn{2}{|c|}{$\begin{array}{l}\text { Percentage of total } \\
\text { caught in area }\end{array}$} \\
\hline & Site $\mathbf{S}$ & Site $\mathbf{M}$ & & Site $\mathbf{S}$ & Site $\mathbf{M}$ \\
\hline Quercus & 11 & 10 & $1 \cdot 1$ & $2 \cdot 1$ & $6 \cdot 9$ \\
\hline Pinus & 15 & 17 & $0 \cdot 9$ & $\mathbf{2 \cdot 9}$ & $11 \cdot 7$ \\
\hline Castanea & 9 & 7 & $\mathbf{1 \cdot 3}$ & $1 \cdot 8$ & $4 \cdot 8$ \\
\hline Other & 5 & $\mathbf{5}$ & $1 \cdot 0$ & $1 \cdot 0$ & $3 \cdot 5$ \\
\hline Grass pollen & 40 & 39 & $\mathbf{1} \cdot \mathbf{0}$ & $7 \cdot 8$ & $26 \cdot 9$ \\
\hline Gramineae & 158 & 56 & $2 \cdot 8$ & $30 \cdot 8$ & $38 \cdot 6$ \\
\hline Weed pollen & & & & & \\
\hline Urtica & 283 & 35 & $8 \cdot 1$ & $55 \cdot 3$ & $24 \cdot 1$ \\
\hline Rumex & 21 & 7 & $3 \cdot 0$ & $4: 1$ & $4 \cdot 8$ \\
\hline Other & 6 & 6 & $1 \cdot 0$ & $1 \cdot 2$ & $4 \cdot 2$ \\
\hline & 310 & 48 & $6 \cdot 5$ & $60 \cdot 5$ & $33 \cdot 1$ \\
\hline Unclassified & 4 & 2 & $2 \cdot 0$ & 0.8 & $1 \cdot 4$ \\
\hline Total & 512 & 145 & $3 \cdot 5$ & $100 \cdot 0$ & $100 \cdot 0$ \\
\hline
\end{tabular}

Hourly variations in pollen content of the air

Gramineae and Urtica pollen were counted hourly from 17 June to 22 June inclusive (Fig. 5), a period chosen because both types fluctuated considerably during it. Both types are liberated during the day, the peak for Urtica pollen coming at noon, and that for grass pollen in the afternoon (Fig. 6). The fact that more grass pollen was in the air on 18 June than on 21 June was possibly because 18 June followed a cool rainy day with little pollen shedding. Hyde (1952) noticed that grass pollen is released in great amounts when a sunny day follows a dull one. Over the period 28 May to 6 June inclusive, Pinus pollen increased steadily after $07.00 \mathrm{hr}$., and most pollen was caught between 09.00 and $13.00 \mathrm{hr}$. at both sites.

\section{Moss and fern spores and algal clumps}

Of these plants moss spores averaged only $0 \cdot 1 / \mathrm{m}^{3}$ at site $S$ and $0 \cdot 3$ at site $\mathbf{M}$. Fern spores averaged $1.7 / \mathrm{m}^{3}$ at $S$ and 1.9 at $M$ and were mainly Pteridium; none was caught in June and most (average $3 \cdot 4$ at $S$ and $4 \cdot 4$ at $M$ ) in August. Algal 


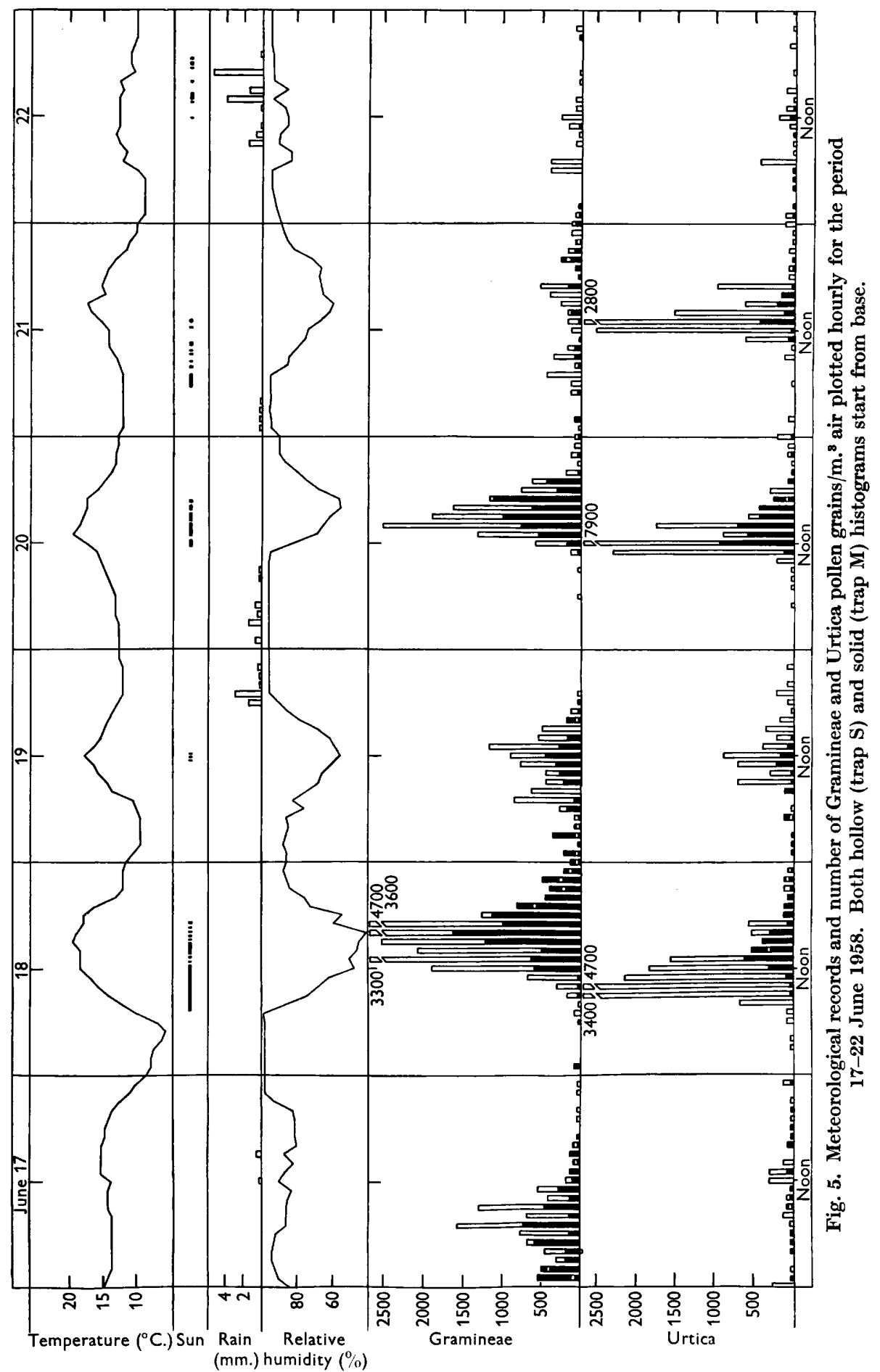

$(\mathrm{mm}$.$) humidity (\%)$ 
clumps, consisting mainly of small groups of cells of Gloeocapsa type (Gregory, Hamilton \& Sreeramulu, 1955), were caught throughout the season and averaged $10 \cdot 9 / \mathrm{m}^{3}$ at $S$ and $7 \cdot 1$ at $M$; more were caught in the early part of the season.

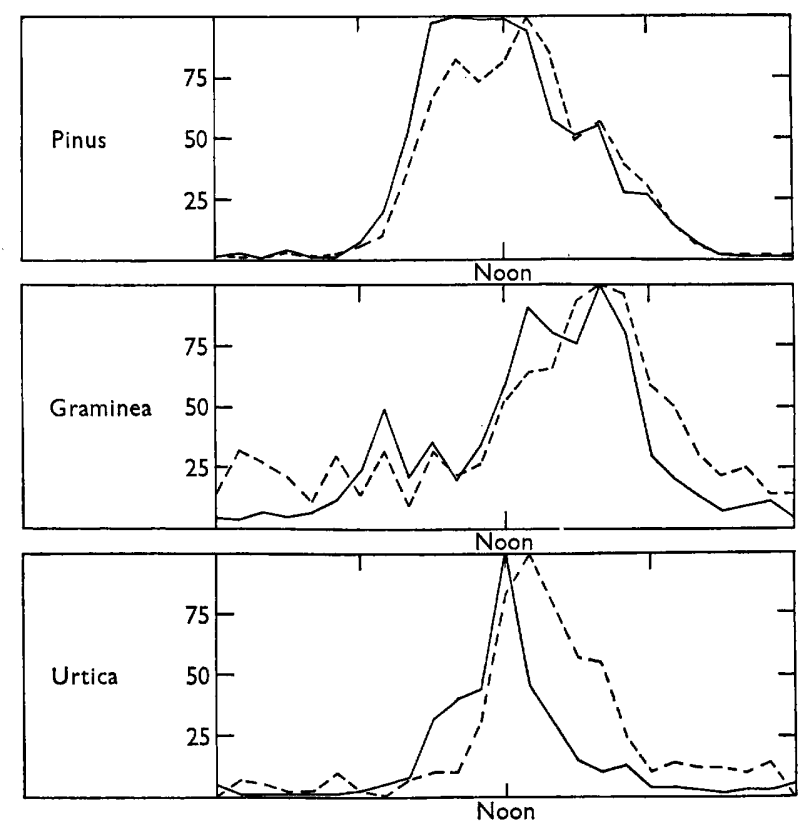

Fig. 6. Diurnal periodicity of Pinus pollen (arithmetic mean of data from 28 May to 6 June 1958), and of Gramineae and Urtica pollen (arithmetic mean of data from 17 to 22 June 1958). - trap $S$; - - $-\operatorname{trap} M$.

\section{DISCUSSION}

The difference between the site $\mathbf{S}$ by the stream and the open hill site $\mathbf{M}$ is striking: over the whole season there were $\mathbf{2 \cdot 6}$ times more spores at site $S$ than at site $\mathbf{M}$ and $\mathbf{3 . 5}$ times as many pollens. The difference is even greater with components of the 'damp air-spora' (Hirst, 1953) such as Sporobolomyces and '3-bar ascospores', and also with those types which were known to have strong local sources near the stream, such as Ganoderma, nettle and grass pollen (near site $\mathbf{M}$ the grass was prevented from flowering by mowing). The seasonal curve for 'total spores' was dominated by Sporobolomyces and to a lesser extent by Cladosporium.

The mean numbers of spores $/ \mathrm{m}^{3}$ at site $\mathrm{M}$, with orifice $0.5 \mathrm{~m}$. above ground level, are similar to those caught by a trap $2 \mathrm{~m}$. above ground level at Rothamsted in 1952 (Table 3), but pollens were fewer at both the Silwood Park sites. Comparison between these two places is reasonable, although the two seasons differed considerably, 1952 being dry and 1958 wet. The site used at Rothamsted was on arable land and was more comparable with site $\mathbf{M}$ than with $\mathbf{S}$ at Silwood Park.

From the differences between the two sites $M$ and $S$ (450 m. apart) it is evident that local ecology of an area is important in determining its air-spora. For example, over the whole season the type referred to as ' 3 -bar ascospores' was 10 times more abundant at $S$ than at M. During the 6 days referred to in Figs. 3 and 4 the difference was 70 times, and the 6347 spores of this type counted at $S$ during this 
6-day period, compared with only 91 at $M$, emphasizes the fact that these spores must be of local origin near the stream. The recorded diurnal periodicity of this fungus at site $\mathbf{S}$ is therefore reliable, but not that at $\mathbf{M}$ (Fig. 5).

The Ganoderma counts near the stream varied greatly from hour to hour (Fig. 4), an effect attributed to the concentrated source some $65 \mathrm{~m}$. west of the trap-a condition where small changes in wind direction could result in large changes in

Table 3. Mean numbers of spores and pollen grains $/ m .^{3}$ of air at Rothamsted from 1 June to 25 October 1952 (Gregory \& Hirst, 1957) and at Silwood Park from 14 May to 25 September 1958

\begin{tabular}{|c|c|c|c|}
\hline & \multirow{2}{*}{$\begin{array}{c}\text { Rothamsted } 1952, \\
2 \mathrm{~m} . \text { above } \\
\text { ground level }\end{array}$} & \multicolumn{2}{|c|}{$\begin{array}{l}\text { Silwood Park 1958, } \\
0.5 \mathrm{~m} \text {. above ground level }\end{array}$} \\
\hline & & Site $\mathbf{S}$ & Site $\mathbf{M}$ \\
\hline Total spores & 11,368 & 29,716 & 11,306 \\
\hline $\left.\begin{array}{l}\text { Sporobolomyces } \\
\text { Tilletiopsis } \\
\text { Hyaline basidiospores }\end{array}\right\}$ & 3,990 & 14,077 & 4,397 \\
\hline Cladosporium & 5,837 & 4,585 & 3,197 \\
\hline Total pollens & 1,184 & 512 & 145 \\
\hline
\end{tabular}

concentration of spores reaching the trap. Whether the diurnal periodicity of Ganoderma observed here (Fig. 5), and also found by Sreeramulu (1959), resulted from decreased spore production during the day is not yet clear. Day temperatures of $19-21^{\circ}$ are unlikely to inhibit sporulation of this species, which is abundant in warm climates. The amount of daylight reaching the basidia must be small and light is not known to inhibit sporulation in this species. Possibly during the daytime the spore cloud is more diluted by greater wind velocity, and diffused by turbulence through a thicker layer of the atmosphere, than it is at night (Hirst, 1953; Gregory, 1961, p. 119); but all these explanations are speculative.

At both trapping sites, $\mathrm{M}$ and $\mathrm{S}$, the catch of Ustilago avenae (perennans) type was clearly correlated with the grass pollen seasonal curves, and both simultaneously declined temporarily in the last week of June. This agrees with observations of Sreeramulu (1959) on the correlation between barley loose smut spore liberation and the anthesis of the barley plant. Although the mechanisms by which the pollen grains and smut spores are released differ, there is a correlation in timing; the natural entrance of the smut spore to the developing grain is through the open flower at anthesis (Malik \& Batts, 1960).

The locality $\mathbf{S}$ evidently acted as a strong local source of spores, and near the sheltered site $\mathbf{S}$ the spore clouds of local origin remained more concentrated because of lower wind speeds. The trees and shrubs near site $\mathrm{S}$ may also have acted as a filter and removed, by catchment on vegetation, some spores of distant origin which easily reached the more exposed trap $\mathbf{M}$; this effect might account for the larger numbers of Boletus and Russula/Lactarius spore types caught at site $M$, though there may also have been richer sources of these larger fungi near to trap $\mathbf{M}$.

The seasonal mean, Table 1, is an average of all concentrations during the season, from zero up to an instantaneous maximum. When shorter time intervals are considered, higher concentrations will be encountered, as illustrated in Table 4. 
The means for the six-day period studied in Figs. $\mathbf{3}$ and $\mathbf{5}$ are usually higher than the seasonal means, and the highest concentration per hour is many times higher still. Table 4 illustrates the general principle that there are many high concentrations of short duration; higher values could still, no doubt, be found by further shortening the time interval.

Table 4. Mean concentrations of spores $/ m .^{3}$ of air, illustrating the occurrence of high concentrations of short duration

\begin{tabular}{|c|c|c|c|c|c|c|c|c|}
\hline \multirow[b]{3}{*}{ Site at Silwood Park } & \multicolumn{4}{|c|}{ Data from whole season } & \multicolumn{4}{|c|}{ Data from 6-day period } \\
\hline & \multicolumn{2}{|c|}{$\begin{array}{c}\begin{array}{c}\text { Mean for } \\
\text { season }\end{array} \\
\end{array}$} & \multicolumn{2}{|c|}{$\begin{array}{l}\text { Highest concen- } \\
\text { tration } / 24 \mathrm{hr} \text {. }\end{array}$} & \multicolumn{2}{|c|}{$\begin{array}{c}\text { Mean for } \\
\text { 6-day period }\end{array}$} & \multicolumn{2}{|c|}{$\begin{array}{l}\text { Highest concen- } \\
\text { tration/hr. }\end{array}$} \\
\hline & $\mathbf{S}$ & $\mathbf{M}$ & $\mathbf{S}$ & M & $\mathbf{S}$ & $\mathbf{M}$ & $\mathbf{S}$ & $\mathbf{M}^{\prime}$ \\
\hline '3-bar ascospores' & $\mathbf{1 , 5 6 9}$ & $\mathbf{1 5 0}$ & 13,440 & $\mathbf{1 , 3 8 0}$ & 3,248 & 47 & 72,150 & $\mathbf{5 2 5}$ \\
\hline Ganoderma & 960 & 172 & 4,020 & 1,290 & 1,123 & 84 & 14,475 & 1,050 \\
\hline Botrytis & 348 & 181 & 2,490 & 780 & 244 & 70 & 1,500 & 750 \\
\hline Gramineae pollen & 158 & 56 & 2,055 & 645 & 375 & 165 & 4,680 & 1,620 \\
\hline Urtica pollen & 283 & 35 & 2,115 & 180 & 352 & 73 & 7,920 & 945 \\
\hline Pinus pollen & 15 & 17 & 255 & 270 & $116^{*}$ & $125 *$ & $1,180^{*}$ & $1,020^{*}$ \\
\hline
\end{tabular}

Although some correlations with weather can be surmised from the results in Figs. 2, 3 and 5, it is impossible to account fully for the observed variations in the air-spora at any locality. Maximum and minimum thermometers and surface wetness recorders working at each trap site would obviously be desirable in future work of this type, to help interpretation. The effects of past weather on development of higher plants and fungi, the effects of immediate weather on spore-release mechanisms, effects of wind and turbulence in diluting the spore cloud, and the presence or absence of local sources, are all so interrelated that far more information is needed before firm conclusions can be drawn.

I thank the Asthma Research Council for the loan of a Hirst spore trap; Dr K. Maunsell for helpful suggestions, M. M. S. Malik, J. Sam Raj and E. E. Green for help in field work, J. W. Siddorn for meteorological data, E. D. Hamilton for help in pollen identification, and R. H. Gregory for working out the diurnal periodicity of Pinus pollen.

\section{REFERENCES}

Gregory, P. H. (1954). The construction and use of a portable volumetric spore trap. Trans. Brit. mycol. Soc. 37, 390.

Gregory, P. H. (1961). The Microbiology of the Atmosphere, p. 251. London: Leonard Hill.

Gregory, P. H., Hamilton, E. D. \& Sreeramulu, T. (1955). Occurrence of the alga Gloeocapsa in the air. Nature, Lond., 176, 1270.

Gregory, P. H. \& Hirst, J. M. (1957). The summer air-spora at Rothamsted in 1952. J. gen. Microbiol. 17, 135.

Gregory, P. H. \& Sreeramulu, T. (1958). Air-spora of an estuary. Trans. Brit. mycol. Soc. 41, 145.

Hamilton, E. D. (1959). Studies on the air spora. Acta allerg., Kbh. 13, 143.

Hirst, J. M. (1952). An automatic volumetric spore trap. Ann. appl. Biol. 39, 257. 
Hirst, J. M. (1953). Changes in atmospheric spore content: diurnal periodicity and the effects of weather. Trans. Brit. mycol. Soc. 36, 375.

Hyde, H. A. (1952). Grass pollen in Great Britain. Acta allerg., Kbh. 5, 98.

Hyde, H. A. (1956). Tree pollen in Great Britain. Acta allerg., Kbh. 10, 224.

Hyde, H. A. (1959). Weed pollen in Great Britain. Acta allerg., Kbh. 13, 186.

Hyde, H. A. \& Adams, K. F. (1958). An Atlas of Airborne Pollen Grains, p. 112. London: Macmillan.

LACEY, M. E. \& GREgory, P. H. (1962). Occurrence in Britain of the fungus causing facial eczema in sheep. Nature, Lond. 193, 85.

MaLik, M. M. S. \& BatTs, C. C. V. (1960). The determination of the reaction of barley varieties to loose smut. Ann. appl. Biol. 48, 39.

MAUnSELL, K. (1958). The seasonal variations of allergic bronchial asthma in relation to the concentration of pollen and fungal spores in the air in 1954, 1955 and 1956. Acta allerg., Kbh. 12, 257.

Sreeramulu, T. (1959). The diurnal and seasonal periodicity of spores of certain plant pathogens in the air. Trans. Brit. mycol. Soc. 42, 177. 